\title{
Fetal bone cells for tissue engineering
}

\author{
Marc-Olivier Montjovent ${ }^{\mathrm{a}}$, Nathalie Burri ${ }^{\mathrm{a}, \mathrm{b}}$, Silke Mark $^{\mathrm{c}}$, Ermanno Federici $^{\mathrm{a}}$, \\ Corinne Scaletta ${ }^{\mathrm{b}}$, Pierre-Yves Zambelli ${ }^{\mathrm{d}}$, Patrick Hohlfeld ${ }^{\mathrm{b}}$, Pierre-François Leyvraz ${ }^{\mathrm{d}}$, \\ Lee L. Applegate ${ }^{b}$, Dominique P. Pioletti ${ }^{a} *$ \\ ${ }^{a}$ Bone Bioengineering Group, Orthopedic Research Center, Swiss Federal Institute of Technology Lausanne, Switzerland \\ ${ }^{\mathrm{b}}$ Laboratory of Fetal Medicine, Department of Obstetrics, CHUV, Lausanne, Switzerland \\ ${ }^{\mathrm{c}}$ Ludwig Institute for Cancer Research, Lausanne Branch, University of Lausanne, Epalinges, Switzerland \\ ${ }^{\mathrm{d}}$ Hôpital Orthopédique de la Suisse Romande, Lausanne, Switzerland
}

Received 27 January 2004; revised 4 June 2004; accepted 2 July 2004

Available online 11 September 2004

\begin{abstract}
We envision the use of human fetal bone cells for engineered regeneration of adult skeletal tissue. A description of their cellular function is then necessary. To our knowledge, there is no description of human primary fetal bone cells treated with differentiation factors. The characterization of fetal bone cells is particularly important as the pattern of secreted proteins from osteoblasts has been shown to change during aging. In the first part of this work, human primary fetal bone cells were compared to adult bone cells and mesenchymal stem cells for their ability to proliferate and to differentiate into osteoblasts in vitro. Cell proliferation, gene expression of bone markers, alkaline phosphatase (ALP) activity, and mineralization were analyzed during a time-course study. In the second part of this paper, bone fetal cells behavior exposed to osteogenic factors is further detailed. The doubling time of fetal bone cells was comparable to mesenchymal stem cells but significantly shorter than for adult bone cells. Gene expression of cbfa-1, ALP, $\alpha 1$ chain of type I collagen, and osteocalcin were upregulated in fetal bone cells after 12 days of treatment, with higher inductions than for adult and mesenchymal stem cells. The increase of ALP enzymatic activity was stronger for fetal than for adult bone cells reaching a maximum at day 10, but lower than for mesenchymal stem cells. Importantly, the mineralization process of bone fetal cells started earlier than adult bone and mesenchymal stem cells. Proliferation of fetal and adult bone cells was increased by dexamethasone, whereas $1 \alpha, 25$-dihydroxyvitamin $\mathrm{D}_{3}$ did not show any proliferative effect. Mineralization studies clearly demonstrated the presence of calcium deposits in the extracellular matrix of fetal bone cells. Nodule formation and calcification were strongly increased by the differentiation treatment, especially by dexamethasone. This study shows for the first time that human primary fetal bone cells could be of great interest for bone research, due to their fast growth rate and their ability to differentiate into mature osteoblasts. They represent an interesting and promising potential for therapeutic use in bone tissue engineering.
\end{abstract}

(C) 2004 Elsevier Inc. All rights reserved.

Keywords: Bone tissue engineering; Differentiation; Human fetal cells; Mesenchymal stem cells; Osteoblast

\section{Introduction}

To address the need of an increasing number of patients who require bone for skeletal reconstruction, surgeons can

Abbreviations: $1 \alpha, 25-(\mathrm{OH})_{2} \mathrm{D}_{3}, 1 \alpha, 25$-dihydroxyvitamin $\mathrm{D}_{3} ; \mathrm{ALP}$, alkaline phosphatase; cbfa-1, core binding factor alpha 1; MSC, mesenchymal stem cells.

* Corresponding author. Bone Bioengineering Group/Orthopedic Research Center, Bâtiment AAB, EPFL, CH 1015 Lausanne, Switzerland. Fax: +41216938660.

E-mail address: dominique.pioletti@epfl.ch (D.P. Pioletti). overcome the disadvantages linked to auto- or allo-bone grafts by choosing the tissue engineering approach $[1,2]$.

This strategy consists of three necessary elements: (1) cells with a high osteogenic potential, easy to obtain and to handle under standardized conditions, (2) osteogenic growth factors, and (3) a synthetic three-dimensional scaffold which gives the construct sufficient mechanical properties for loading and facilitates vascularization.

The cell origin and type are essential aspects in bone tissue engineering. This has been recapitulated by different articles, particularly in the field concerning bone marrow- 
derived stem cells [3-5]. As one of every 100,000 nucleated cells derived from bone marrow is a stem cell, a procedure of isolation is required to decrease the volume of material injected [6]. Recently, a highly purified population of stromal stem cells derived from human bone marrow was described [7]. Exposure to growth factors or the combination with fibrillar collagen increased the proliferation of stem cells and their differentiation into osteoblastic cells $[8,9]$. However, the number of human mesenchymal stem cells with osteogenic potential was shown to decrease early during aging [10], and the proliferation of human bone marrow stromal cells was reported to be negatively correlated with the age of the donor in vitro [11].

Periosteal cells have been widely used in bone tissue engineering by isolating osteoprogenitor cells from the patient's periosteum and seeding them into bioresorbable scaffolds [12-16].

Fetal-associated tissues such as placenta, amniotic liquid, or umbilical cord are described to be potential source of cells for tissue engineering [17-20]. In contrast to embryonic derived up to the end of the eighth week, beginning at the ninth week, cells are considered as fetal and tissue dissection as organ donation. Human fetal liver cells have been already used for transplantation to treat severe immunodeficiencies, hematological disorders, and inborn errors of metabolism, when there was no perfectly matched donor for marrow transplantation [21]. Neuronal affections such as Huntington [22] or Parkinson disease [23] have been treated by transplantation of fresh fetal neuroblasts. Unfortunately, these cells are difficult to expand in culture and have to be transplanted freshly therefore needing large quantities of fresh tissue [24]. Recently, human fetal skin cells derived from one cell bank $\left(1-4 \mathrm{~cm}^{2}\right.$ tissue results in over 10.5 million fetal skin constructs) were used in clinical trials, and new advances in tissue therapy are possible with cellular constructs obtained from ex vivo cultures (Hohlfeld, J. submitted). Engineered regeneration of human skeletal adult tissues could be also developed using human fetal bone cells. To evaluate their potential integration in a bone engineering strategy, a biological characterization of these cells is necessary. To our knowledge, there is no available description of human primary fetal bone cells behavior when treated with factors of differentiation.

Age-dependent biology of osteoblasts is generally accepted [25]. The particular biology of human primary fetal bone cells was partially demonstrated with cells isolated from calvaria [26]. They were found to secrete primarily matrix constituents proteins in culture, whereas adult cells produce additionally proteins involved in matrix turnover. Age-dependent differences regarding the osteoblastic synthesis of osteoanabolic peptides and their impact on the regeneration of osseous defects were observed with a rat calvaria model [27].

Osteoblast development follows three main phases: proliferation, matrix synthesis, and mineralization [28]. Factors for differentiation of osteoblasts are well de- scribed $[29,30]$ and include ascorbic acid, $\beta$-glycerophosphate, $1 \alpha, 25$-dihydroxyvitamin $\mathrm{D}_{3}\left(1 \alpha, 25-(\mathrm{OH})_{2} \mathrm{D}_{3}\right)$, and dexamethasone.

The aim of this work was to study the characteristics of human primary fetal bone cells for a better comprehension of their biology in vitro and to evaluate their potential use for tissue engineering in comparison to adult bone cells and mesenchymal stem cells. In the first part of this paper, fetal bone cells, adult bone cells, and mesenchymal stem cells are compared for their self-renewal capacity and their osteogenic induction when treated with differentiation mix. Their osteoblastic phenotype is presented at the gene expression level, such as the core binding factor alpha 1 (cbfa-1), a critical transcription factor for osteoblast differentiation and function [31-33]; alkaline phosphatase (ALP) [34]; $\alpha 1$ chain of type I collagen, which represents $85-90 \%$ of the total organic bone matrix [35]; and osteocalcin, which constitutes $1-2 \%$ of the total protein of bone [36]. At the protein level, ALP enzymatic activity and the ability of matrix mineralization are observed. In the second part of this paper, the effects of different osteoinductor factors on human primary fetal bone cells are examined to further characterize their ability to differentiate.

\section{Materials and methods}

\section{Cell sources}

Human fetal and adult bone cells were obtained from our bank of bone cells comprising 32 adult donors (18 females and 14 males) and 4 fetal donors ( 1 female and 3 males) at the end of March 2004. More than 250 primary total hip replacements with potentially interesting orthopedic tissue samples were performed during the year 2002 at the Hôpital Orthopédique de la Suisse Romande. Documents relative to the patients were consulted to assure no major disease, medications, or alcohol consumption. Bone samples were extensively collected, and care was taken to obtain healthy bone samples. In particular, the selected adult bone cells are coming from donors without bone necrosis. In this study, human trabecular bone biopsies at femoral locations obtained from 31-, 50-, and 60-year-old adult women subsequent to orthopedic surgery and from fetus of 13 , 14 , and 16 weeks' gestational age following voluntary interruption of pregnancy were used. Biopsies were obtained in accordance with the Ethics Committee of University Hospital in Lausanne (Ethical Protocol 51/01). Primary osteoblast cultures were established by rinsing the tissue first with PBS (containing penicillin and streptomycin). Afterwards, bone samples were mechanically dissociated with a scalpel blade and transferred to $10-\mathrm{cm}$ culture grade plates where cell outgrowth was seen within 2 to 5 days under normal culture conditions : DMEM Glutamax (Invitrogen, Carlsbad, CA), 10\% FCS (Sigma-Aldrich, St. Louis, MO). Commercially available mesenchymal stem 
cells (Cambrex Bio Science, Walkersville, MD), isolated from the posterior iliac crest of the pelvic bone from young and healthy volunteers, were tested parallelly.

\section{Cell culture}

Fetal and adult bone cells were maintained in culture by passaging once a week and culturing at $37^{\circ} \mathrm{C}$ in an humidified, $5 \% \mathrm{CO}_{2}$ atmosphere in DMEM Glutamax, $10 \%$ FCS. Mesenchymal stem cells were expanded in MSCGM growth medium (Cambrex Bio Science). Culture media were changed twice a week.

For the comparison between fetal bone cells, adult bone cells, and mesenchymal stem cells, $1 \alpha, 25-(\mathrm{OH})_{2} \mathrm{D}_{3} 10 \mathrm{nM}$ (Alexis Biochemicals, San Diego, CA), dexamethasone 10 $\mathrm{nM}$ (Sigma-Aldrich), additionally to L-ascorbic acid $50 \mu \mathrm{g} /$ $\mathrm{ml}$ (Sigma-Aldrich), and $\beta$-glycerophosphate $1 \mathrm{mM}$ (Sigma-Aldrich) were added in their respective growth medium to obtain the full differentiation mix. For the characterization of fetal bone cells, osteogenic factors were tested as follows: ascorbic acid $50 \mu \mathrm{g} / \mathrm{ml}$ and $\beta$-glycerophosphate $1 \mathrm{mM}$ (minimal differentiation mix); ascorbic acid $50 \mu \mathrm{g} / \mathrm{ml}, \beta$-glycerophosphate $1 \mathrm{mM}$, and dexamethasone $10 \mathrm{nM}$ (dexamethasone mix); ascorbic acid $50 \mu \mathrm{g} / \mathrm{ml}$, $\beta$-glycerophosphate $1 \mathrm{mM}$, and $1 \alpha, 25-(\mathrm{OH})_{2} \mathrm{D}_{3} 10 \mathrm{nM}$ (vitamin $\mathrm{D}_{3} \mathrm{mix}$ ); and ascorbic acid $50 \mu \mathrm{g} / \mathrm{ml}, \beta$-glycerophosphate $1 \mathrm{mM}$, dexamethasone $10 \mathrm{nM}$, and $1 \alpha, 25$ $(\mathrm{OH})_{2} \mathrm{D}_{3} 10 \mathrm{nM}$ (full differentiation mix). In general, passage 3 was used for all experiments. Concerning fetal bone cells, the same assays were performed at passage 6 to verify their multilineage capability. Each procedure was repeated three times, starting from a new vial of cells which were stored in liquid $\mathrm{N}_{2}$. Unless otherwise stated, results presented were obtained with the 16-week-old donor for the fetal source and the 50-year-old donor for the adult bone cells (Table 1). Similar data were obtained with two other fetal and adult donors.

\section{Cell proliferation}

To determine their doubling time, cells were seeded at a density of 440,000 cells/T75 flask. Every day, up to 10 days, triplicates were washed twice with PBS, and cells were detached using trypsin-EDTA (Invitrogen). Subsequently, the cell number was determined in a counting chamber (Marienfeld $\mathrm{GmbH} \&$ Co. KG, Lauda-Koenigshofen, Germany). The growth constant and the generation time were determined during the exponential cell growth [37].

To evaluate the effects of osteogenic factors on proliferation, cells were seeded at 5000 cells/well in 96-well plates and incubated for $24 \mathrm{~h}$ at $37^{\circ} \mathrm{C}$ in a humidified, $5 \%$ $\mathrm{CO}_{2}$ atmosphere in normal culture medium. The medium was then replaced by $100 \mu \mathrm{l} /$ well fresh medium containing the factors of differentiation. Every second day, up to 12 days, a plate was analyzed for cell proliferation, and the medium of the remaining plates was renewed. Measure-
Table 1

Comparison of the doubling time of human fetal bone, adult bone, and mesenchymal stem cells

\begin{tabular}{llll}
\hline \multicolumn{4}{l}{ A. Fetal bone cells } \\
\hline Donor & Age (weeks) & Passage 3 (h) & Passage 6 (h) \\
\hline 1 & 16 & $27.0( \pm 0.2)$ & $30.2( \pm 1.5)$ \\
2 & 14 & $22.6( \pm 0.5)$ & $25.1( \pm 0.7)$ \\
3 & 13 & $30.3( \pm 0.1)$ & $31.4( \pm 0.1)$ \\
& & & \\
\hline B. Adult bone cells & & \\
\hline Donor & Age (years) & Passage 3 (h) \\
\hline 1 & 60 & $248.7( \pm 20.1)$ & \\
2 & 50 & $170.5( \pm 11.8)$ \\
3 & 31 & $151.6( \pm 5.6)$ &
\end{tabular}

\begin{tabular}{lll}
\hline \multicolumn{3}{l}{ C. Mesenchymal stem cells } \\
\hline Donor & Age (years) & Passage $3(\mathrm{~h})$ \\
\hline 1 & 26 & $26.5( \pm 0.9)$ \\
\hline
\end{tabular}

Experiments were performed in triplicates and presented as mean values $( \pm \mathrm{SEM})$

ments were performed in triplicate for each time point. The relative number of viable cells in each well was determined with the CellTiter $96^{\mathrm{R}}$ AQueous One Solution Cell Proliferation Assay (Promega, Madison, WI) according to the manufacturer's instructions. This colorimetric method is based on the bioreduction of the MTS tetrazolium compound into a colored formazan product which is soluble in culture medium. It was determined to produce a linear relationship between the number of viable cells and the absorbance at $490 \mathrm{~nm}$.

Briefly, $20 \mu \mathrm{l}$ of the reagent solution was added to each well, including three wells containing only medium for background subtraction. After incubation for $90 \mathrm{~min}$ at $37^{\circ} \mathrm{C}$, the absorbance was recorded at $490 \mathrm{~nm}$ using a Wallac 1420 VICTOR $^{2}$ multilabel plate reader (Wallac Oy, Turku, Finland).

\section{$R N A$ isolation and purification}

Cells were seeded in 6-cm Petri dishes at a density of 300,000 cells/dish. Treatment began $24 \mathrm{~h}$ later, with culture media changed every second day. At the same time points, samples were removed for gene expression analysis. RNA isolation and purification procedures were performed using Nucleospin $^{\mathrm{R}}$ RNA II columns (Macherey-Nagel, Düren, Germany) with the furnished protocol. RNA was eluted in $40 \mu \mathrm{l}$ of RNase-free water and stored at $-80^{\circ} \mathrm{C}$ until required.

\section{First strand synthesis}

For each sample, $5 \mu \mathrm{l}$ of total RNA was reversetranscribed using the Taqman Universal polymerase chain reaction (PCR) reagents with random hexamers (Applied Biosystems, Foster City, CA). Reaction volumes were fixed 
at $50 \mu \mathrm{l}$ according to the protocol provided by the supplier. The thermal cycler PCT-0100 (MJ Research, Waltham, MA) was programmed as follows: $25^{\circ} \mathrm{C} 10 \mathrm{~min}, 48^{\circ} \mathrm{C} 30 \mathrm{~min}$, and $95^{\circ} \mathrm{C} 5 \mathrm{~min}$.

\section{Real time polymerase chain reaction}

Specific primers for cbfa- $1, \alpha 1$ chain of type I collagen, osteocalcin, ALP, and for the housekeeping 18S RNA were designed with the Primer Express ${ }^{\mathrm{R}}$ software (Applied Biosystems) and purchased from Integrated DNA Technologies (Coralville, IA). An additional sequence of $18 \mathrm{bp}$ was added to the 5' end of every forward primer to use the Amplifluor ${ }^{\circledR}$ Uniprimer ${ }^{\circledR}$ technology (Intergen Discovery Products, Purchase, NY). PCR reactions were performed in $25 \mu \mathrm{l}: 5 \mu \mathrm{l}$ of first strand, $12.5 \mu \mathrm{l}$ of TaqMan Universal PCR Master Mix (Applied Biosystems), and $7.5 \mu \mathrm{l}$ of the primers working solution. Thermal cycle conditions were $50^{\circ} \mathrm{C} 2$ $\mathrm{min}, 95^{\circ} \mathrm{C} 10 \mathrm{~min}$, then 50 cycles at $95^{\circ} \mathrm{C} 15 \mathrm{~s}, 60^{\circ} \mathrm{C} 1 \mathrm{~min}$. Amplifications were monitored with the ABI Prism 7700 (Applied Biosystems). Measurements were performed in duplicates for each time point. Relative gene expressions were analyzed with the $2^{-\Delta \Delta \mathrm{CT}}$ method [38]. Normalized to 18S RNA, each gene expression was compared with the $\triangle \mathrm{CT}$ calibrator value from the untreated group. PCR products were purified using Wizard ${ }^{\circledR}$ SV gel and PCR Clean-Up system (Promega) and sequenced with the ABI Prism 3100 Genetic Analyser, using the Big Dye Terminator v3.1 Cycle Sequencing Kit Chemistry (Applied Biosystems). Results were in accordance with the expected sequences (data not shown).

\section{Alkaline phosphatase activity}

Cells were seeded at 5000 cells/well in 96 -well plates and incubated for $24 \mathrm{~h}$ at $37^{\circ} \mathrm{C}$ in a humidified, $5 \% \mathrm{CO}_{2}$ atmosphere in normal culture medium. The medium was then replaced with $100 \mu \mathrm{l} /$ well fresh medium containing the osteogenic factors. Every second day, up to 12 days, a plate was analyzed for the alkaline phosphatase activity, and the medium in the remaining plates was renewed at this occasion. Measurements were performed in triplicates for each time point. Alkaline phosphatase activity was determined using $p$-nitrophenol tablets as substrate (SigmaAldrich). The ALP activity values were normalized to the total protein content determined using the total cellular protein assay (see below). Calculations were done according to the manufacturer's instructions (Sigma, procedure $n^{\circ} 245$ ).

\section{Total cellular protein}

Cells were seeded at the same density as for the alkaline phosphatase activity assay, and same treatments were applied. At each time point, cells were rinsed twice with PBS, and the total protein was determined in cell lysates using the Bio-Rad protein assay (Bio-Rad Laboratories,
Hercules, CA). Measurements were performed in triplicates for each time point. Total protein values were quantified using a standard curve obtained with a serial dilutions of bovine serum albumin contained in the Bio-Rad Protein Assay Standard II (Bio-Rad Laboratories).

\section{In vitro mineralization}

Cells were seeded at 5000 cells/well in 96-well plates and incubated for $24 \mathrm{~h}$ at $37^{\circ} \mathrm{C}$ in a humidified, $5 \% \mathrm{CO}_{2}$ atmosphere in normal culture medium. The medium was then replaced by the differentiation factors. The experiment was performed twice, with 5 wells for each condition. The medium was renewed every second day. Up to 6 weeks, every week, a plate was analyzed for mineralization. MC3T3 E1 cells were used as positive control. The degree of in vitro calcium deposition was determined using Von Kossa staining. Briefly, the medium was removed from the wells, and the cells were rinsed three times with PBS. After washing, the
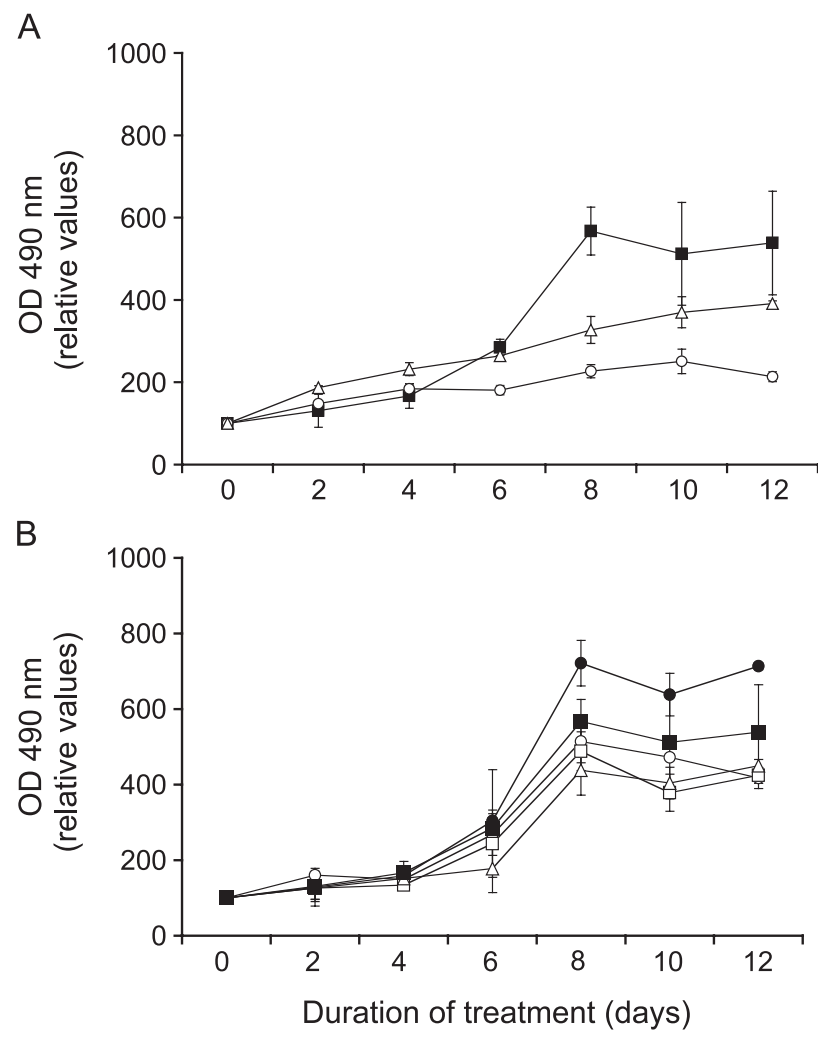

Fig. 1. (A) Proliferation curves of fetal bone cells ( $\square)$, adult bone cells ( $\mathrm{O}$ ), and mesenchymal stem cells $(\triangle)$. Cells were treated with ascorbic acid $50 \mu \mathrm{g} / \mathrm{ml}, \beta$-glycerophosphate $1 \mathrm{mM}$, dexamethasone $10 \mathrm{nM}$, and $1 \alpha, 25$ $(\mathrm{OH})_{2} \mathrm{D}_{3} 10 \mathrm{nM}$ (full differentiation mix). (B) Proliferation of fetal bone treated with ascorbic acid $50 \mu \mathrm{g} / \mathrm{ml}$ and $\beta$-glycerophosphate $1 \mathrm{mM}$ (minimal differentiation mix, $\square$ ); ascorbic acid $50 \mu \mathrm{g} / \mathrm{ml}, \beta$-glycerophosphate $1 \mathrm{mM}$ and dexamethasone $10 \mathrm{nM}$ (dexamethasone mix, $\bullet$ ); ascorbic acid $50 \mu \mathrm{g} / \mathrm{ml}, \beta$-glycerophosphate $1 \mathrm{mM}$, and $1 \alpha, 25-(\mathrm{OH})_{2} \mathrm{D}_{3} 10 \mathrm{nM}$ (vitamin $\mathrm{D}_{3} \mathrm{mix}, \triangle$ ); ascorbic acid $50 \mu \mathrm{g} / \mathrm{ml}, \beta$-glycerophosphate $1 \mathrm{mM}$, dexamethasone $10 \mathrm{nM}$, and $1 \alpha, 25-(\mathrm{OH})_{2} \mathrm{D}_{3} 10 \mathrm{nM}$ (full differentiation mix, -). Optical densities are expressed as ratios relative to day 0 levels. Results are shown as the mean \pm SEM of three experiments performed in triplicate. Media were renewed every second day. 
cells were fixed for $5 \mathrm{~min}$ in neutral formalin $10 \%$. The formalin was removed, and the cells were washed three times with deionized water. The cells were then stained with $\mathrm{AgNO}_{3}$ solution 5\% (in water). The plates were exposed for 1 $\mathrm{h}$ under UV light and washed three times with water. The water was removed, and a solution of sodium-thiosulfate $5 \%$ (in water) was added for 2 min. Finally, cells were washed three times with water, and samples were examined for black clusters by light microscopy.

\section{Scanning electron microscopy}

Fetal bone cells were seeded at 100,000 cells/well in 6well plates and treated during 6 weeks under the same conditions as described for the mineralization assay. Subsequently, cells were fixed with glutaraldehyde, followed by a dehydration procedure in ethanol. The sample surfaces were gold-coated during 2 min under $1 \mathrm{kV}$ and observed using a scanning electron microscope Philips XL30 (FEI, Hillsboro, OR) at a voltage of $5 \mathrm{kV}$.

\section{Statistical analyses}

Data were analyzed using the two-way ANOVA to determine the difference between cells behaviors (XLSTAT, Addinsoft, Brooklyn, NY). The Fisher LSD test was used to
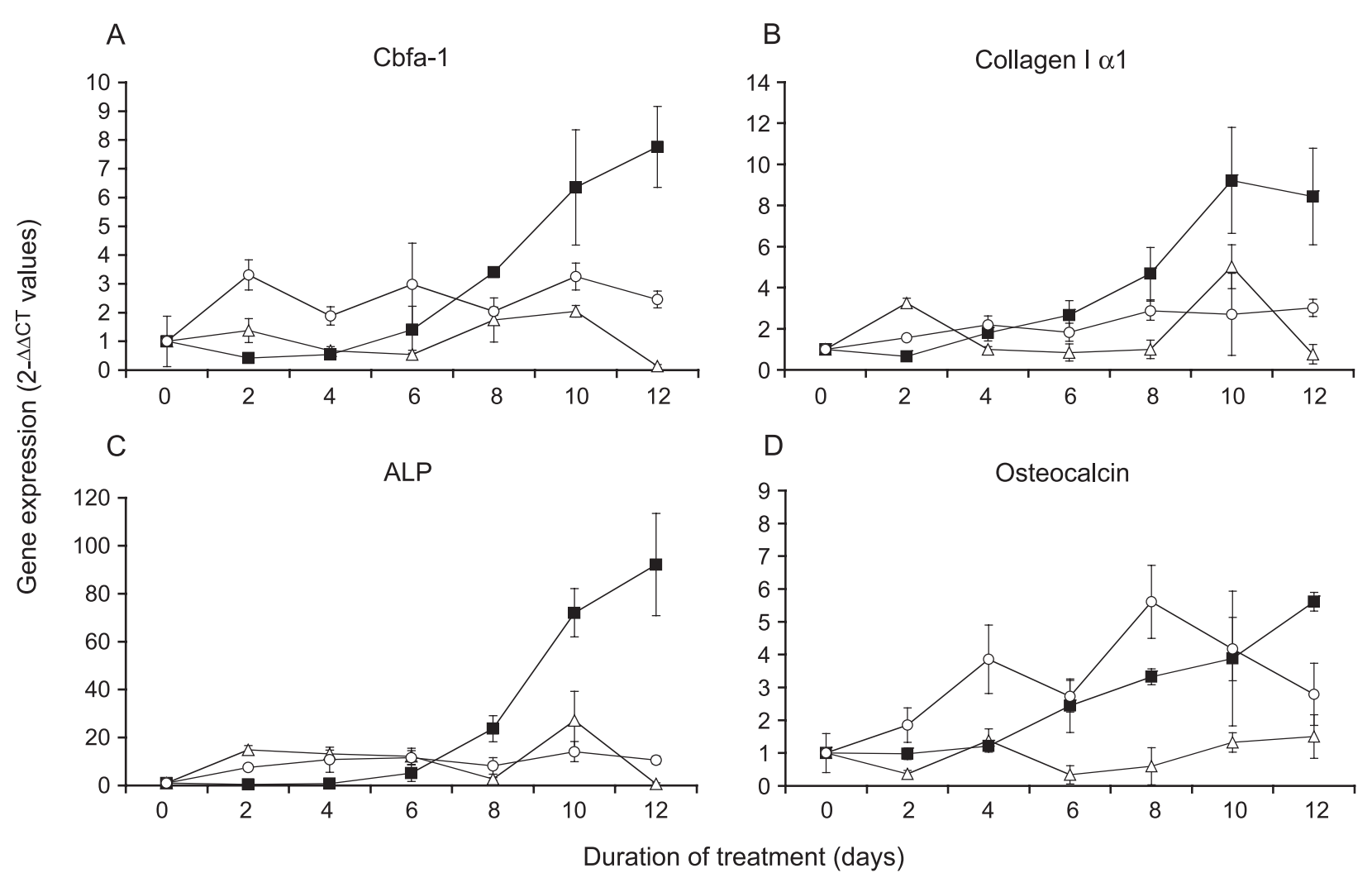

Fig. 2. Gene expression of cbfa-1 (A), $\alpha 1$ chain of type I collagen (B), alkaline phosphatase (C), and osteocalcin (D) quantified by RT-PCR after exposure to ascorbic acid $50 \mu \mathrm{g} / \mathrm{ml}, \beta$-glycerophosphate $1 \mathrm{mM}$, dexamethasone $10 \mathrm{nM}$, and $1 \alpha, 25-(\mathrm{OH})_{2} \mathrm{D}_{3} 10 \mathrm{nM}$ (full differentiation mix). Media were renewed every second day. The expression of fetal bone cells $(\boldsymbol{\square})$, adult bone cells $(O)$, and mesenchymal stem cells $(\triangle)$ are shown as $2^{-\Delta \Delta C T}$ values, relative to their respective untreated group. Results are plotted as the mean $\pm \mathrm{SEM}$ of three individual experiments.

determine statistical significance between sample sets. A value of $P<0.05$ was taken as a significant difference. The same approach was used to evaluate the effects of differentiation factors on bone fetal cells. Results are shown as the mean \pm SEM. Comparisons of proliferation and ALP enzymatic activity between cells are expressed as ratios of respective inductions. Effects of the different osteogenic treatments on bone fetal cells are expressed as percent (\%) change versus the reference.

\section{Results}

\section{Cell proliferation}

Growth curves obtained for human primary fetal and adult bone cells show that the former proliferated considerably more rapidly than mature cells which displayed a much slower and clearly age-dependent doubling time. For fetal bone cells, it was determined by cell counting to vary between 23 and $27 \mathrm{~h}$, depending on the donor (Table 1). A similar value was obtained with mesenchymal stem cells. For adult bone cells derived from a 31- and 50-year-old donor, it was determined to be 152 and $170 \mathrm{~h}$, respectively, while cells coming from a 60 -year-old donor showed a doubling time even as slow as $249 \mathrm{~h}$.

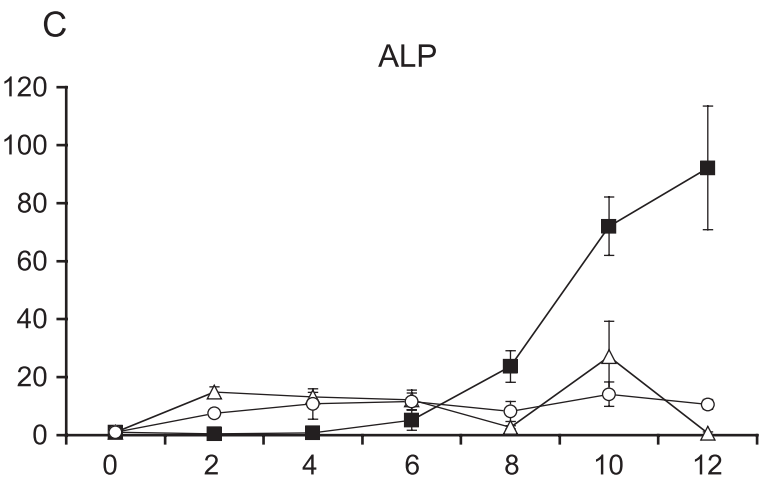


The induction of proliferation with the full differentiation mix was significantly higher for the fetal bone cells than for the adult bone cells starting from day (d) 6 until the end of the experiment (Fig. 1A). Maximum difference was observed at day $12(252.3 \%$ of the induction of adult bone cells, $P<0.01$ ). For this parameter, there was no significant difference between the mesenchymal stem cells and the fetal bone cells treated with osteogenic factors.

Dexamethasone had a positive effect on proliferation of fetal bone cells (Fig. 1B). Compared to the minimal differentiation mix, it was significatively higher starting at day 8 . This difference was observed with the same range until the end of the experiment (d8: $+47 \%, P<0.05$; d10: $+69 \%, P<0.0091$; d12: $+68 \%, P<0.0022)$. Conversely, the vitamin $\mathrm{D}_{3}$ mix did not have a proliferative effect. When added together with dexamethasone, $1 \alpha, 25-(\mathrm{OH})_{2} \mathrm{D}_{3}$ reduced the growth rate significantly at day 12 , compared to dexamethasone alone $(-24 \%, P<0.033)$.

\section{Gene expression}

Results of relative gene expression obtained by real-time RT-PCR for cbfa-1, $\alpha 1$ chain of type I collagen, ALP, and osteocalcin are shown in Fig. 2 for human primary fetal bone cells in comparison with adult bone cells and mesenchymal stem cells. Cbfa-1 gene expression (Fig. 2A) of fetal bone cells started to increase at day 6 and reached a maximum at day 12 with a 3 -fold higher upregulation than observed for the adult bone cells $(315.9 \% ; P=0.001)$ and a 56 -fold higher upregulation than obtained for the mesenchymal stem cells $(5586.5 \% ; P=0.002)$ at this time point. Strongest upregulation of the $\alpha 1$ chain of type I collagen gene (Fig. 2B) was also observed for the fetal bone cells. At day 12, fetal bone cells showed a significantly higher level of gene expression than adult bone cells $(279.5 \% ; P=0.0112)$ and mesenchymal stem cells $(1108.7 \% ; P=0.0022)$. For the fetal bone cells, upregulation of the ALP gene (Fig. 2C) started at day 6 and increased continuously until day 12 . At this time point, strongest differences in gene expression were observed with a 9-fold higher upregulation compared to adult bone cells $(875 \% ; P=0.0011)$ and an even 140 -fold higher expression than obtained for mesenchymal stem cells $(13,635 \% ; P=0.0006)$. Osteocalcin gene expression (Fig. 2D) of fetal bone cells was induced slowly and late, with a significantly higher upregulation of the gene in fetal bone cells than in adult bone cells $(201.2 ; P=0.0126)$ and in mesenchymal stem cells $(372.9 \% ; P=0.0022)$ at the end of the experiment.

\section{Alkaline phosphatase activity}

The induction of ALP enzymatic activity with the full differentiation mix was significantly higher for the mesenchymal stems cells than for the fetal and the adult bone cells starting from day 4 until the end of the experiment (Fig.
3A). Maximum difference was observed at day $6(255.9 \%$ of the induction of fetal bone cells, $P<0.001$, and $487.6 \%$ of adult bone cells induction, $P<0.0003$ ). Compared with adult bone cells, fetal bone cells showed a higher induction of ALP enzymatic activity with a maximum difference at day $10(222.2 \%, P<0.0007)$. Detailed effects on ALP activity of $1 \alpha, 25-(\mathrm{OH})_{2} \mathrm{D}_{3}$ and dexamethasone when added to ascorbic acid and $\beta$-glycerophosphate for fetal bone cells are shown in Fig. 3B. ALP enzymatic activity was enhanced in the group treated with the full differentiation mix, with a first significant difference comparing with the DMEM group at day 4 (d4: $+322 \%, P<0.0179$; d6: $+84 \%, P<$ 0.0054; d8: $+530 \%, P<0.002$; d10: $+183 \%, P<0.0001$; d12: $+283 \%, P<0.0002)$. The dexamethasone mix had also an increasing effect but starting at day $6(\mathrm{~d} 6:+81 \%, P<$ 0.0067 ; d8: $+541 \%, P<0019$; d10: $+246 \%, P<0.0001$; d12: $+188 \% P<0.0042$ ). A comparable pattern was observed with adult bone cells, but the inductions were reduced comparatively to fetal bone cells (data not shown).
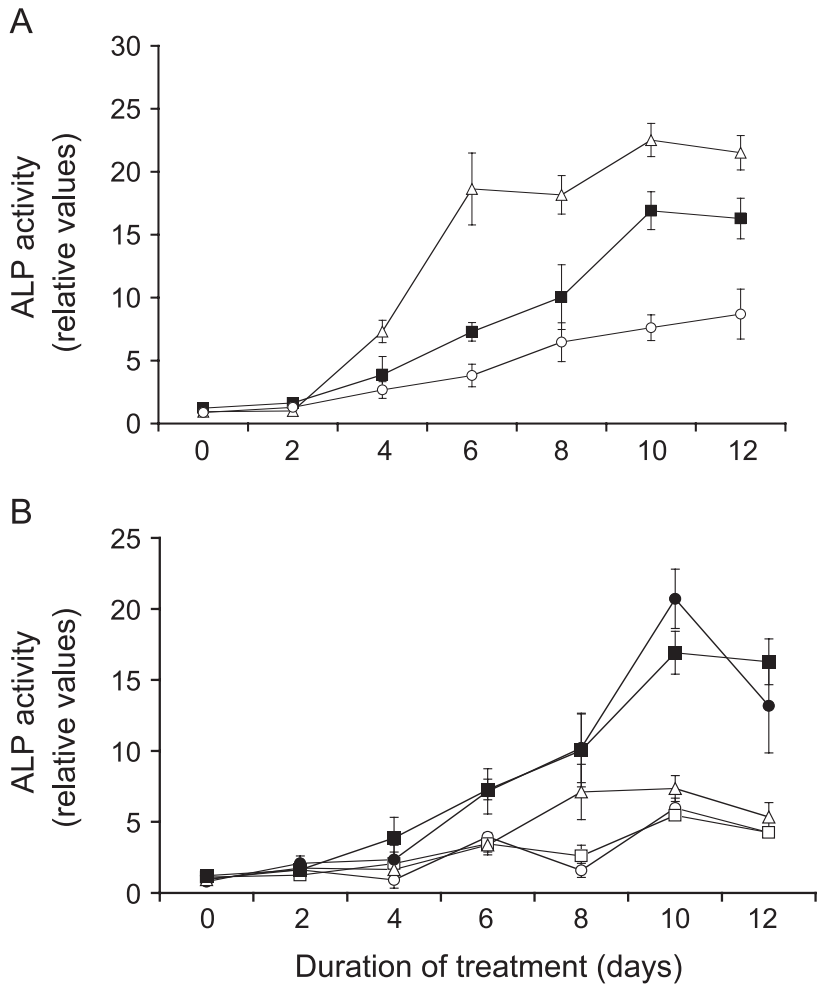

Fig. 3. (A) ALP enzymatic activity of fetal bone cells ( $\mathbf{\square})$, adult bone cells $(\mathrm{O})$, and mesenchymal stem cells $(\triangle)$. Cells were treated with ascorbic acid $50 \mu \mathrm{g} / \mathrm{ml}, \beta$-glycerophosphate $1 \mathrm{mM}$, dexamethasone $10 \mathrm{nM}$, and $1 \alpha, 25$ $(\mathrm{OH})_{2} \mathrm{D}_{3} 10 \mathrm{nM}$ (full differentiation mix). (B) ALP enzymatic activity of fetal bone cells treated with ascorbic acid $50 \mu \mathrm{g} / \mathrm{ml}$ and $\beta$-glycerophosphate $1 \mathrm{mM}$ (minimal differentiation mix, $\square$ ); ascorbic acid $50 \mu \mathrm{g} / \mathrm{ml}, \beta-$ glycerophosphate $1 \mathrm{mM}$, and dexamethasone $10 \mathrm{nM}$ (dexamethasone mix, -); ascorbic acid $50 \mu \mathrm{g} / \mathrm{ml}, \beta$-glycerophosphate $1 \mathrm{mM}$, and $1 \alpha, 25$ $(\mathrm{OH})_{2} \mathrm{D}_{3} 10 \mathrm{nM}$ (vitamin $\mathrm{D}_{3}$ mix, $\triangle$ ); ascorbic acid $50 \mu \mathrm{g} / \mathrm{ml}, \beta$ glycerophosphate $1 \mathrm{mM}$, dexamethasone $10 \mathrm{nM}$, and $1 \alpha, 25-(\mathrm{OH})_{2} \mathrm{D}_{3} 10$ $\mathrm{nM}$ (full differentiation mix, $\mathbf{\square}$ ). Ratios relative to the untreated group at day 0 are shown. Results are expressed as the mean \pm SEM of three experiments performed in triplicate. Media were renewed every second day. 


\section{In vitro mineralization}

First positive Von Kossa staining of fetal bone cells was obtained after 2 weeks of treatment with the full differentiation mix (Fig. 4A), as for MC3T3 E1 used as positive control (data not shown). In contrast, adult bone cells and mesenchymal stem cells did not show positive Von Kossa staining after 2 weeks of treatment, but after 5 and 3 weeks of treatment, respectively (data not shown). The same patterns as for the fetal cells were then obtained treating these cells for a longer period (data not shown). Further studies on fetal bone cells showed that dexamethasone did strongly increase in vitro calcium deposition, whereas $1 \alpha, 25-(\mathrm{OH})_{2} \mathrm{D}_{3}$ did not show a comparable effect (Fig. 4B). Nodule formation was visible after the first week and strongly enhanced starting from the second week of treatment for fetal cells receiving the full differentiation mix (Fig. 5A), whereas no obvious difference was observed for

A

Fetal

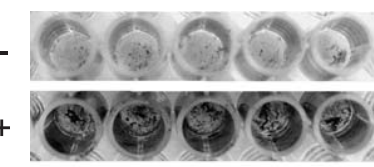

Adult

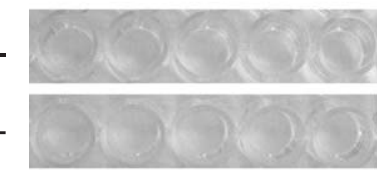

MSC

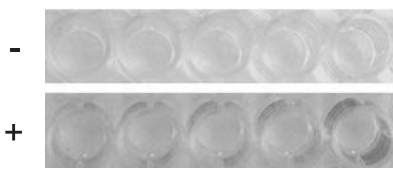

B

Control

Asc.ac/b-gly

Asc.ac/b-gly/dexa

Asc.ac/b-gly/vitD3

Asc.ac/b-gly/dexa/vitD3

A

Control

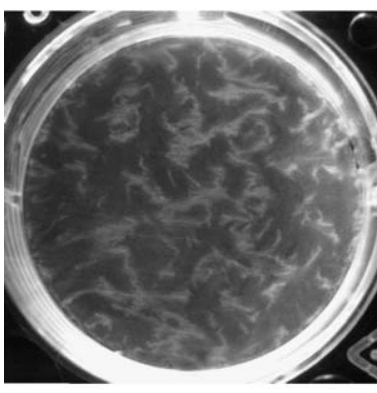

B
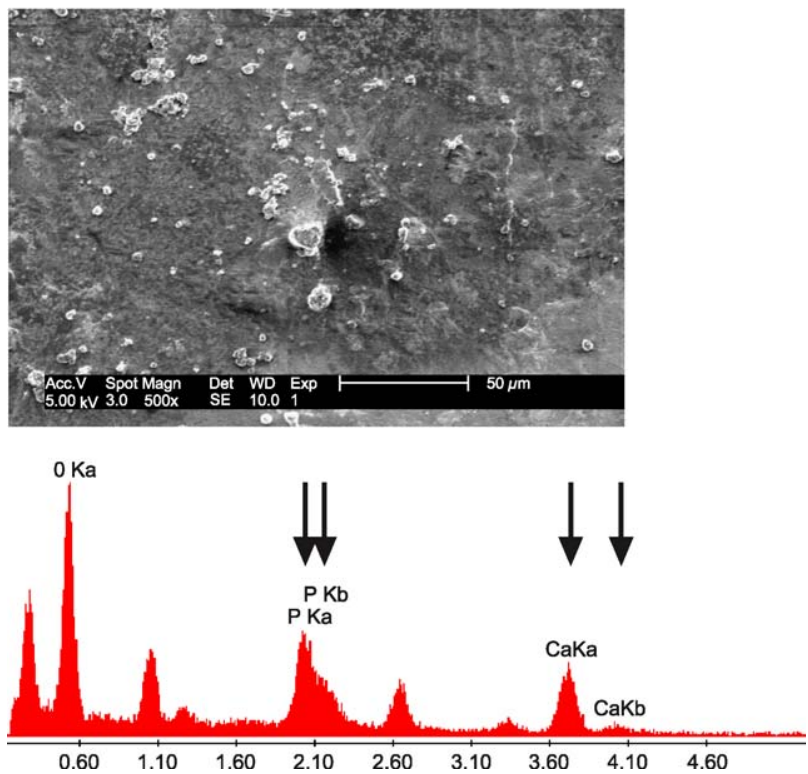

Fig. 5. (A) Bone-like nodule formation observed with fetal bone cells after 2 weeks. Control group and group treated with ascorbic acid $50 \mu \mathrm{g} / \mathrm{ml}$, $\beta$ glycerophosphate $1 \mathrm{mM}$, dexamethasone $10 \mathrm{nM}$, and $1 \alpha, 25-(\mathrm{OH})_{2} \mathrm{D}_{3} 10 \mathrm{nM}$ (full differentiation mix) are shown. First nodules were detected in the control group after the first week, and their number was increasing with time. (B) Extracellular matrix of fetal bone cells after 4 weeks of treatment with ascorbic acid $50 \mu \mathrm{g} / \mathrm{ml}, \beta$-glycerophosphate $1 \mathrm{mM}$, dexamethasone $10 \mathrm{nM}$, and $1 \alpha, 25-(\mathrm{OH})_{2} \mathrm{D}_{3} 10 \mathrm{nM}$ (full differentiation mix). SEM micrograph and SEM energy dispersive $\mathrm{x}$-rays spectroscopy analysis are presented. Arrows indicate characteristic peaks of energy corresponding to $\mathrm{Ca}$ and $\mathrm{P}$ elements. Media were renewed every second day.

adult cells at this time point (data not shown). Interestingly, fetal bone cells were able to constitute nodules even without any treatment of differentiation. When observed by scanning electron microscopy after 4 weeks of treatment, highly organized structures containing layers of cells trapped in an abundant collagenous matrix and aggregates were distinguishable in these nodules. Energy dispersive $\mathrm{x}$-rays spectroscopy analysis did clearly identify the characteristic peaks of energy corresponding to $\mathrm{Ca}$ and $\mathrm{P}$ elements, indicating that in vitro mineralization occurred (Fig. 5B). Nodules were observed for adult cells starting from the fifth week and calcium phosphate crystal deposits 1 week later (data not shown). and $1 \alpha, 25-(\mathrm{OH})_{2} \mathrm{D}_{3} 10 \mathrm{nM}$ (full differentiation mix). Media were renewed every second day. 


\section{Discussion}

The aim of this work was to investigate the osteoblastic potential of human primary fetal bone cells in vitro and to evaluate their possible use for tissue engineering. We first compared the behavior of bone fetal cells to adult bone and mesenchymal stem cells for their responsiveness to osteogenic factors. Then we characterized fetal bone cells in more details for their ability to be induced into the bone pathway. A key finding was the observation of spontaneous bone-like nodule formation after only 2 weeks and before adult cells and mesenchymal stem cells. Additionally, fetal bone cells showed a strong response to differentiation factors.

The growth rate of fetal bone cells was similar to mesenchymal stem cells, but faster than the growth rate of bone cells from a 31-year-old donor. The proliferative ability was even slower with cells obtained from older donors (Table 1). This age dependency was already observed and could be attributed to a decrease of proliferative precursor cells on trabecular bone surfaces [39]. However, age-dependent changes in the population of osteoprogenitor cells are discussed controversially. Recent results have given evidence of aging in marrow stromal progenitor cells $[10,40-46]$. Other reports demonstrated that osteogenic progenitor cells were maintained during aging [47-49]. The question of changes in the osteoprogenitor cell population with age is further complicated by the possibility of sex-dependent differences [50-52]. Age-related osteoponia may also depend from the skeletal site, depending to the variable trabecular-cortical bone ratio at different locations [53]. The proliferative aptitude is of major interest in the perspective to use human primary fetal bone cells for research or tissue engineering: a rapid expansion facilitates the creation of an important bank of cells, starting from one donor. Remarkably, the high capacity for self-renewal in vitro did correlate with telomerase activity for fetal cells, as demonstrated by the telomerase repeat amplification protocol assay (data not shown). In addition to its role in cell replication, telomerase is required for differentiation of murine bone marrow mesenchymal stem cells in vitro [54]. A possible mechanism leading to in vitro accelerated osteogenesis by telomerized bone marrow stromal stem cells could be attributed to the upregulation of the osteogenic genes cbfa-1, osteorix and osteocalcin [7]. The presence of ascorbic acid and $\beta$-glycerophosphate had no effect on proliferation. This observation was previously described for rat calvaria osteoblasts in cultures which maintained the same growth rate when $\beta$-glycerophosphate was added to ascorbic acid [28]. Dexamethasone accelerated the proliferation of both fetal and adult bone cells. When treated with dexamethasone or basic fibroblast growth factor, adult cells were proliferating faster but significantly slower than fetal cells from the untreated DMEM group (data not shown). Although $1 \alpha, 25-(\mathrm{OH})_{2} \mathrm{D}_{3}$ did not have any effect on proliferation compared with the minimal differentiation mix, its presence slowed down the positive effect of dexamethasone. This was detected with fetal as well as with adult cells. The combining action of the two hormones was described to strongly increase the adipocyte population and their differentiation but to decrease the osteoblastic cell population in a long-term rat bone marrow culture [55]. Osteoblastic cell proliferation and differentiation were increased by dexamethasone and inhibited by $1 \alpha, 25-(\mathrm{OH})_{2} \mathrm{D}_{3}$. Our findings are in accordance with these observations, and further studies are needed to address the issues concerning adipocyte differentiation.

During this proliferative sequence, genes involved in the production and deposition of extracellular matrix started to be expressed which denotes a strong osteogenic potential of primary fetal bone cells compared to adult and mesenchymal stem cells. The induction of cbfa-1 gene expression observed is essential for osteoblast function and differentiation. It is also a critical gene involved in bone matrix deposition [56]. Early upregulation of collagen I $\alpha 1$ confirmed its induction before any other current matrix component and prior to ALP [28,57,58]. Fetal cell gene expression of ALP was augmented due to the presence of dexamethasone, $1 \alpha, 25-(\mathrm{OH})_{2} \mathrm{D}_{3}$, ascorbic acid, and $\beta$ glycerophosphate. The time course of ALP gene expression roughly fits with the increase of activity of this enzyme. These results are consistent with previous studies where the regulation of ALP by glucocorticoids was ascertained at protein and mRNA levels [59-61]. Exposing the rat osteosarcoma cell line ROS 17/2.8 to dexamethasone, the rise in alkaline phosphatase mRNA levels could be attributed entirely to an increase in gene transcription [62]. The immortalized human fetal osteoblastic cell line hFOB/ ER9 showed an increase of ALP activity during mineralization [63], whereas in rat fetal calvaria cultures, ALP was expressed maximally during the early stages of differentiation [28]. In our model, ALP activity of fetal bone cells reached a maximum activity after 10 days, when nodule formation started to be markedly enhanced. ALP enzymatic activity of mesenchymal stem cells was also strongly enhanced by osteogenic factors. Adult bone cells showed the same pattern for ALP enzymatic activity, with an earlier induction for the full differentiation mix, compared with the group receiving only dexamethasone additionally to ascorbic acid and $\beta$-glycerophosphate (data not shown). For adult cells, ALP enzymatic activity was observed to vary according to the age of the donor as previously demonstrated [64].

Osteocalcin, one of the most abundant noncollagenous proteins in bone, was also upregulated at the gene expression level, first in adult bone cells, and later in fetal bone cells. This was not observed with mesenchymal stem cells during the first 12 days of treatment, indicating that their extracellular matrix maturation was not as advanced as fetal cells. The delayed mineralization observed with mesenchymal stem cells in comparison with fetal cells could be due to their less differentiated phenotype. Corroborating this observation, osteocalcin gene expression 
is controlled by cbfa-1 [31], and mesenchymal stem cells did not upregulate their cbfa-1 expression during the treatment. Although its biological function has not been precisely defined, specific interaction with hydroxyapatite was demonstrated [65]. New evidence indicates that osteocalcin participates in the regulation of mineralization and bone turnover [28]. A vitamin D regulatory element was identified in its promoter [66-69]. In most species, $1 \alpha, 25-$ $(\mathrm{OH})_{2} \mathrm{D}_{3}$ upregulates osteocalcin biosynthesis. Upregulation of osteocalcin indicated that fetal bone cells were fully differentiated into osteoblasts and started to mineralize. This was in accordance with the fact that in vitro calcium deposition was observed by Von Kossa staining after 2 weeks of treatment. Nodule formation increased gradually and was maximum at the end of the treatment (data not shown). Dexamethasone augmented the nodule number dramatically, when added to ascorbic acid and $\beta$-glycerophosphate. Comparable results were obtained with murine embryonic stem cells [70]. In primary rat calvaria cell cultures, additional nodule formation was observed, and the self-renewal capacity of the bone-nodule forming cells was increased [71]. This could be due to the induction of proliferation of more mature osteoblast precursors, enabling them to achieve sufficient numbers of cell divisions to form a visible nodule, or the effect targeted a separate subpopulation of progenitors requiring glucocorticoid to proliferate and/or differentiate $[10,72]$. The existence of subpopulations of osteoblasts that differs in their responsiveness to dexamethasone was previously suggested in clonal rat osteosarcoma cells [73].

Furthermore, characterization of the mineralized bone nodules by scanning electron microscopy clearly demonstrated that they were made of osteoblasts, extracellular collagen fibrils, and crystal deposits. Detailed analysis of the crystals by energy dispersive $\mathrm{X}$-rays spectroscopy showed that these structures were containing $\mathrm{Ca}$ and $\mathrm{P}$ elements. Such a substratum produced by differentiating osteoblasts was described as an anchorage for calcifying collagen fibers synthesized by the same cells in a rat model [74]. Signs of mineralization are fundamental in perspective to use primary fetal bone cells for artificial bone synthesis.

For this study, the number of passages was arbitrarily fixed to 3. Similar results concerning fetal bone cells proliferation rate, ALP activity, and in vitro mineralization were obtained at passage 6 (data not shown), demonstrating that the multilineage capability was maintained.

In conclusion, our data support the idea that human primary fetal bone cells are able to differentiate into mature osteoblasts when stimulated. This full differentiation process displayed the appearance of specifically mineralized bone-like nodules. Due to their more rapid growing rate and their strong responsiveness to differentiation treatment compared with adult cells and mesenchymal stem cells, their use could be of great interest for fundamental research, pharmaceutical screenings, and especially for bone tissue engineering.

\section{Acknowledgments}

We thank Arlette Kottelat from the Bone Bioengineering Group (EPFL-CRO) for excellent technical assistance, Laurence Mathieu from the Laboratory of Composite and Polymer Technology (EPFL-LTC) for her outstanding work, and the research center in electron microscopy (EPFL-CIME). This study was supported by grants from the Swiss National Science Foundation (PNR 46), the Fondation Lémanique pour la Recherche sur le Tissu Osseux, and by the Lausanne Center for Bone Tissue Engineering.

\section{References}

[1] Parikh SN. Bone graft substitutes: past, present, future. J Postgrad Med 2002;48:142-8.

[2] Petite H, Viateau V, Bensaid W, Meunier A, de Pollak C, Bourguignon $\mathrm{M}$, et al. Tissue-engineered bone regeneration. Nat Biotechnol 2000; 18:959-63.

[3] Caplan AI, Bruder SP. Mesenchymal stem cells: building blocks for molecular medicine in the 21st century. Trends Mol Med 2001; 7:259-64

[4] Anselme K. Osteoblast adhesion on biomaterials. Biomaterials 2000; 21:667-81

[5] Ohgushi H, Caplan AI. Stem cell technology and bioceramics: from cell to gene engineering. J Biomed Mater Res 1999;48:913-27.

[6] Connolly J, Guse R, Lippiello L, Dehne R. Development of an osteogenic bone-marrow preparation. J Bone Jt Surg Am 1989; 71:684-91

[7] Gronthos S, Chen S, Wang CY, Robey PG, Shi S. Telomerase accelerates osteogenesis of bone marrow stromal stem cells by upregulation of CBFA1, osteorix, and osteocalcin. J Bone Miner Res 2003; 18:716-22

[8] Tiedeman JJ, Connolly JF, Strates BS, Lippiello L. Treatment of nonunion by percutaneous injection of bone marrow and demineralized bone matrix. An experimental study in dogs. Clin Orthop 1991;294-302.

[9] Cornell CN, Lane JM, Chapman M, Merkow R, Seligson D, Henry S, et al. Multicenter trial of Collagraft as bone graft substitute. J Orthop Trauma 1991;5:1-8.

[10] D'Ippolito G, Schiller PC, Ricordi C, Roos BA, Howard GA. Agerelated osteogenic potential of mesenchymal stromal stem cells from human vertebral bone marrow. J Bone Miner Res 1999;14:1115-22.

[11] Schecroun N, Delloye C. Bone-like nodules formed by human bone marrow stromal cells: comparative study and characterization. Bone $2003 ; 32: 252-60$

[12] Hutmacher DW, Sittinger M. Periosteal cells in bone tissue engineering. Tissue Eng 2003;9(Suppl. 1):S45.

[13] Schantz JT, Hutmacher DW, Chim H, Ng KW, Lim TC, Teoh SH. Induction of ectopic bone formation by using human periosteal cells in combination with a novel scaffold technology. Cell Transplant 2002; $11: 125-38$

[14] Vacanti CA, Bonassar LJ, Vacanti MP, Shufflebarger J. Replacement of an avulsed phalanx with tissue-engineered bone. N Engl J Med 2001;344:1511-4.

[15] Isogai N, Landis WJ, Mori R, Gotoh Y, Gerstenfeld LC, Upton J, et al. Experimental use of fibrin glue to induce site-directed osteogenesis from cultured periosteal cells. Plast Reconstr Surg 2000;105: 953-963.

[16] Breitbart AS, Grande DA, Kessler R, Ryaby JT, Fitzsimmons RJ, Grant RT. Tissue engineered bone repair of calvarial defects using cultured periosteal cells. Plast Reconstr Surg 1998;101:567-74. 
[17] Kaviani A, Guleserian K, Perry TE, Jennings RW, Ziegler MM, Fauza DO. Fetal tissue engineering from amniotic fluid. J Am Coll Surg 2003;96:592-7.

[18] Kadner A, Hoerstrup SP, Tracy J, Breymann C, Maurus CF, Melnitchouk S, et al. Human umbilical cord cells: a new cell source for cardiovascular tissue engineering. Ann Thorac Surg 2002; 74:S1422.

[19] Kaviani A, Perry TE, Barnes CM, Oh JT, Ziegler MM, Fishman SJ, et al. The placenta as a cell source in fetal tissue engineering. J Pediatr Surg 2002;37:995-9.

[20] Mitka M. Amniotic cells show promise for fetal tissue engineering. JAMA 2001;286:2083.

[21] Touraine JL, Roncarolo MG, Bacchetta R, Raudrant D, Rebaud A, Laplace S, et al. Fetal liver transplantation: biology and clinical results. Bone Marrow Transplant 1993;11(Suppl.1):119-22.

[22] Rosser AE, Dunnett SB. Neural transplantation in patients with Huntington's disease. CNS Drugs 2003;17:853-67.

[23] Clarkson ED. Fetal tissue transplantation for patients with Parkinson's disease: a database of published clinical results. Drugs Aging 2001;18:773-85.

[24] Freeman TB. From transplants to gene therapy for Parkinson's disease. Exp Neurol 1997;144:47-50.

[25] Erdmann J, Kogler C, Diel I, Ziegler R, Pfeilschifter J. Age-associated changes in the stimulatory effect of transforming growth factor beta on human osteogenic colony formation. Mech Ageing Dev 1999; 110:73-85.

[26] Johansen JS, Williamson MK, Rice JS, Price PA. Identification of proteins secreted by human osteoblastic cells in culture. J Bone Miner Res 1992;7:501-12.

[27] Kramer FJ, Meyer M, Schliephake H. In vivo administration of purified supernatant of fetal and postnatal osteoblast cultures: initial results. Mund-Kiefer-Gesichtschir 2000;4(Suppl. 2):S485-S9.

[28] Owen TA, Aronow M, Shalhoub V, Barone LM, Wilming L, Tassinari MS, et al. Progressive development of the rat osteoblast phenotype in vitro: reciprocal relationships in expression of genes associated with osteoblast proliferation and differentiation during formation of the bone extracellular matrix. J Cell Physiol 1990;143:420-30.

[29] Gallagher JA. Human osteoblast culture. Methods Mol Med 2003;80:3-18

[30] Aubin JE. Advances in the osteoblast lineage. Biochem Cell Biol 1998;76:899-910.

[31] Ducy P. Cbfa1: a molecular switch in osteoblast biology. Dev Dyn 2000;219:461-71.

[32] Karsenty G. Role of cbfa1 in osteoblast differentiation and function. Semin Cell Dev Biol 2000;11:343-6.

[33] Franceschi RT. The developmental control of osteoblast-specific gene expression: role of specific transcription factors and the extracellular matrix environment. Crit Rev Oral Biol Med 1999;10:40-57.

[34] Zernik J, Twarog K, Upholt WB. Regulation of alkaline phosphatase and alpha 2(I) procollagen synthesis during early intramembranous bone formation in the rat mandible. Differentiation 1990;44:207-15.

[35] Termine JD, Robey PG. Primer on the metabolic bone diseases and disorders of mineral metabolism. Philadelphia: Lippincott-Raven; 1996.

[36] Aubin JE, Liu F. The osteoblastic lineage. In: Bilezikian JP, Raisz LG, Rodan GA, editors. Principles of bone biology. San Diego, CA, USA: Academic Press; 1996. p. 51-67.

[37] Stephenson FH. Calculations for molecular biology and biotechnology. San Diego: Academic Press; 2003.

[38] Livak KJ, Schmittgen TD. Analysis of relative gene expression data using real-time quantitative PCR and the 2(-Delta Delta C(T)) Method. Methods 2001;25:402-8

[39] Shigeno Y, Ashton BA. Human bone-cell proliferation in vitro decreases with human donor age. J Bone Jt Surg Br 1995;77:139-42.

[40] Nishida S, Endo N, Yamagiwa H, Tanizawa T, Takahashi HE. Number of osteoprogenitor cells in human bone marrow markedly decreases after skeletal maturation. J Bone Miner Metab 1999;17:171-7.
[41] Rodriguez JP, Garat S, Gajardo H, Pino AM, Seitz G. Abnormal osteogenesis in osteoporotic patients is reflected by altered mesenchymal stem cells dynamics. J Cell Biochem 1999;75:414-23.

[42] Inoue K, Ohgushi H, Yoshikawa T, Okumura M, Sempuku T, Tamai $\mathrm{S}$, et al. The effect of aging on bone formation in porous hydroxyapatite: biochemical and histological analysis. J Bone Miner Res 1997;12:989-94.

[43] Majors AK, Boehm CA, Nitto H, Midura RJ, Muschler GF. Characterization of human bone marrow stromal cells with respect to osteoblastic differentiation. J Orthop Res 1997;15:546-57.

[44] Bergman RJ, Gazit D, Kahn AJ, Gruber H, McDougall S, Hahn TJ. Age-related changes in osteogenic stem cells in mice. J Bone Miner Res 1996;11:568-77.

[45] Quarto R, Thomas D, Liang CT. Bone progenitor cell deficits and the age-associated decline in bone repair capacity. Calcif Tissue Int 1995;56:123-9.

[46] Egrise D, Martin D, Vienne A, Neve P, Schoutens A. The number of fibroblastic colonies formed from bone marrow is decreased and the in vitro proliferation rate of trabecular bone cells increased in aged rats. Bone 1992;13:355-61

[47] Lee HS, Huang GT, Chiang H, Chiou LL, Chen MH, Hsieh CH, et al. Multipotential mesenchymal stem cells from femoral bone marrow near the site of osteonecrosis. Stem Cells 2003;21:190-9.

[48] Stenderup K, Justesen J, Eriksen EF, Rattan SI, Kassem M. Number and proliferative capacity of osteogenic stem cells are maintained during aging and in patients with osteoporosis. J Bone Miner Res 2001;16:1120-9.

[49] Oreffo RO, Bord S, Triffitt JT. Skeletal progenitor cells and ageing human populations. Clin Sci (Lond) 1998;94:549-55.

[50] Bellows CG, Pei W, Jia Y, Heersche JN. Proliferation, differentiation and self-renewal of osteoprogenitors in vertebral cell populations from aged and young female rats. Mech Ageing Dev 2003;124:747-57.

[51] Muschler GF, Nitto H, Boehm CA, Easley KA. Age- and genderrelated changes in the cellularity of human bone marrow and the prevalence of osteoblastic progenitors. J Orthop Res 2001;19:117-25.

[52] Katzburg S, Lieberherr M, Ornoy A, Klein BY, Hendel D, Somjen D. Isolation and hormonal responsiveness of primary cultures of human bone-derived cells: gender and age differences. Bone 1999;25:667-73.

[53] Martinez ME, del Campo MT, Medina S, Sanchez M, SanchezCabezudo MJ, Esbrit P, et al. Influence of skeletal site of origin and donor age on osteoblastic cell growth and differentiation. Calcif Tissue Int 1999;64:280-6

[54] Liu L, DiGirolamo CM, Navarro PA, Blasco MA, Keefe DL. Telomerase deficiency impairs differentiation of mesenchymal stem cells. Exp Cell Res 2004;294:1-8.

[55] Atmani H, Chappard D, Basle MF. Proliferation and differentiation of osteoblasts and adipocytes in rat bone marrow stromal cell cultures: effects of dexamethasone and calcitriol. J Cell Biochem 2003; 89:364-72.

[56] Yamaguchi A, Komori T, Suda T. Regulation of osteoblast differentiation mediated by bone morphogenetic proteins, hedgehogs, and cbfa1. Endocr Rev 2000;21:393-411.

[57] Liu F, Malaval L, Aubin JE. Global amplification polymerase chain reaction reveals novel transitional stages during osteoprogenitor differentiation. J Cell Sci 2003;116:1787-96.

[58] Liu F, Malaval L, Gupta AK, Aubin JE. Simultaneous detection of multiple bone-related mRNAs and protein expression during osteoblast differentiation: polymerase chain reaction and immunocytochemical studies at the single cell level. Dev Biol 1994;166:220-34.

[59] Hicok KC, Thomas T, Gori F, Rickard DJ, Spelsberg TC, Riggs BL. Development and characterization of conditionally immortalized osteoblast precursor cell lines from human bone marrow stroma. J Bone Miner Res 1998;13:205-17.

[60] Noda M, Rodan GA. Type beta transforming growth factor (TGF beta) regulation of alkaline phosphatase expression and other phenotyperelated mRNAs in osteoblastic rat osteosarcoma cells. J Cell Physiol 1987;133:426-37. 
[61] Majeska RJ, Nair BC, Rodan GA. Glucocorticoid regulation of alkaline phosphatase in the osteoblastic osteosarcoma cell line ROS 17/2.8. Endocrinology 1985;116:170-9.

[62] Green E, Todd B, Heath D. Mechanism of glucocorticoid regulation of alkaline phosphatase gene expression in osteoblast-like cells. Eur J Biochem 1990;188:147-53.

[63] Robinson JA, Harris SA, Riggs BL, Spelsberg TC. Estrogen regulation of human osteoblastic cell proliferation and differentiation. Endocrinology 1997;138:2919-27.

[64] Sutherland MS, Rao LG, Muzaffar SA, Wylie JN, Wong MM, McBroom RJ, et al. Age-dependent expression of osteoblastic phenotypic markers in normal human osteoblasts cultured long-term in the presence of dexamethasone. Osteoporos Int 1995;5:335-43.

[65] Hauschka PV, Wians Jr FH. Osteocalcin-hydroxyapatite interaction in the extracellular organic matrix of bone. Anat Rec 1989;224:180-8.

[66] Demay MB, Gerardi JM, DeLuca HF, Kronenberg HM. DNA sequences in the rat osteocalcin gene that bind the 1,25-dihydroxyvitamin D3 receptor and confer responsiveness to 1,25-dihydroxyvitamin D3. Proc Natl Acad Sci U S A 1990;87:369-73.

[67] Markose ER, Stein JL, Stein GS, Lian JB. Vitamin D-mediated modifications in protein-DNA interactions at two promoter elements of the osteocalcin gene. Proc Natl Acad Sci U S A 1990;87: $1701-1705$.
[68] Morrison NA, Shine J, Fragonas JC, Verkest V, McMenemy ML, Eisman JA. 1,25-dihydroxyvitamin D-responsive element and glucocorticoid repression in the osteocalcin gene. Science 1989;246: $1158-1161$

[69] Kerner SA, Scott RA, Pike JW. Sequence elements in the human osteocalcin gene confer basal activation and inducible response to hormonal vitamin D3. Proc Natl Acad Sci U S A 1989;86:4455-9.

[70] Buttery LD, Bourne S, Xynos JD, Wood H, Hughes FJ, Hughes SP, et al. Differentiation of osteoblasts and in vitro bone formation from murine embryonic stem cells. Tissue Eng 2001;7:89-99.

[71] Bellows CG, Heersche JN, Aubin JE. Determination of the capacity for proliferation and differentiation of osteoprogenitor cells in the presence and absence of dexamethasone. Dev Biol 1990;140:132-8.

[72] Fromigue O, Marie PJ, Lomri A. Differential effects of transforming growth factor beta2, dexamethasone and 1,25-dihydroxyvitamin D on human bone marrow stromal cells. Cytokine 1997;9:613-23.

[73] Hodge BO, Kream BE. Variable effects of dexamethasone on protein synthesis in clonal rat osteosarcoma cells. Endocrinology 1988;122: $2127-2133$

[74] Davies JE, Ottensmeyer P, Shen X, Hashimoto M, Peel SAF. Early extracellular matrix synthesis by bone cells. In: Davies JE, editor. The bone-biomaterial interface. Toronto: University of Toronto Press; 1991. p. $214-25$. 